\title{
Nutritional deficiency in citrus with symptoms of citrus variegated chlorosis disease
}

\author{
Silva-Stenico, ME. ${ }^{\text {* }}$, Pacheco, FTH. ${ }^{\mathrm{a}}$, Pereira-Filho, ER. ${ }^{\mathrm{b}}$, \\ Rodrigues, JLM. ${ }^{\mathrm{c}}$, Souza, AN. ${ }^{\mathrm{a}}$, Etchegaray, A. ${ }^{\mathrm{d}}$, Gomes, JE. ${ }^{\mathrm{a}}$ and Tsai, SM. ${ }^{\mathrm{a}}$

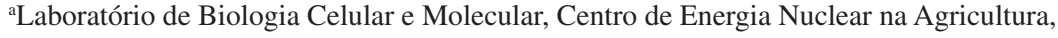 \\ Universidade de São Paulo - USP, \\ CP 96, CEP 13400-970, Piracicaba, SP, Brazil

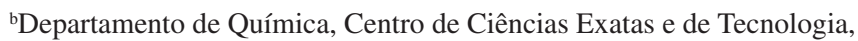 \\ Universidade Federal de São Carlos - UFSCar, \\ CP 676, CEP 13565-905, São Carlos, SP, Brazil \\ ${ }^{\mathrm{c}}$ Department of Biology, The University of Texas - Arlington, $501 \mathrm{~S}$. \\ Nedderman Drive B17A Life Science Building Arlington, TX 76019, USA

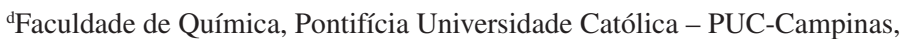 \\ CP 317, CEP 13012-970, Campinas, SP, Brazil \\ *e-mail: estela@cena.usp.br
}

Received August 17, 2007 - Accepted February 25, 2008 - Distributed August 31, 2009

(With 4 figures)

\begin{abstract}
It is well known that citrus plants that have been infected by Xylella fastidiosa display nutritional deficiencies, probably caused by production of extracellular polymers by the bacteria that block normal nutrient flow through the xylem. The aim of this work was to study the mineral composition of specific foliar areas in different stages of infection in citrus. Thus, the concentrations of macro and micronutrients in leaves of citrus infected by $X$. fastidiosa were measured. Samples from four infected citrus orchards in the State of São Paulo, Brazil, were respectively collected from Santa Rita do Passa Quatro, Neves Paulista, Gavião Peixoto and Paraíso counties. The presence of X. fastidiosa in leaves was confirmed by polymerase chain reaction (PCR) using specific PCR primers. To understand the variation in leaf-nutrient content in citrus plants, we used foliar nutrient values from control (non-symptomatic) plants as a reference. Chemometric analysis showed that the deficiency of $\mathrm{P}$ and $\mathrm{K}$ in symptomatic trees for all orchards and high concentrations of $\mathrm{Fe}, \mathrm{Mn}$ and $\mathrm{Zn}$ were observed in chlorotic areas, although other studies revealed deficiency of zinc in leaves. This is the first report showing that a correlation between chlorotic citrus leaf and higher concentrations of $\mathrm{Fe}, \mathrm{Mn}$ and $\mathrm{Zn}$ are observed when infected and healthy plants were compared.
\end{abstract}

Keywords: citrus, nutrition, Xylella fastidiosa, CVC disease, chemometry.

\section{Deficiência nutricional em citros com sintomas da doença da clorose variegada dos citros}

\begin{abstract}
Resumo
Já é bem conhecido que cultivares cítricas que foram infectadas pela bactéria Xylella fastidiosa apresentam deficiências nutricionais devido à produção de polímero extracelular por esta bactéria, o qual bloqueia o fluxo normal de nutriente pelo xilema. O objetivo deste trabalho foi o de estudar a composição mineral em áreas foliares específicas em diferentes fases de infecção na planta. Assim, as concentrações de macro e micronutrientes em folhas de citros infectados por $X$. fastidiosa foram quantificadas. Foram coletadas amostras de quatro pomares cítricos infectados localizados em: Santa Rita do Passa Quatro, Neves Paulista, Gavião Peixoto e Paraíso, no Estado de São Paulo. A presença de $X$. fastidiosa em folhas foi confirmada através de reação da polimerase em cadeia (PCR) usando iniciadores específicos. Para entender a variação no conteúdo de nutriente foliar em plantas cítricas, utilizou-se de valores de nutrientes foliares de plantas não sintomáticas (controle) como referência. A análise quimiométrica mostrou que a deficiência de $\mathrm{P}$ e $\mathrm{K}$ em plantas sintomáticas e concentrações altas de Fe, Mn e Zn foram presentes em áreas foliares cloróticas, embora outros estudos mostrem a deficiência de zinco em folhas. Este é o primeiro relato indicando que uma correlação entre folhas cítricas cloróticas e elevadas concentrações de Fe, Mn e Zn foi observada quando plantas infectadas e saudáveis foram comparadas.
\end{abstract}

Palavras-chave: citros, nutrição, Xylella fastidiosa, doença do CVC, quimiometria. 


\section{Introduction}

Citrus variegated chlorosis (CVC) was considered one of the main problems affecting sweet orange (Citrus sinensis L. Osbeck) orchards of São Paulo and Minas Gerais States, in Brazil. At initial stages, it is characterised by the occurrence of localised symptoms on fruits, leaves and branches. The development of CVC disease affects the host plant metabolism and induces morphological alterations in leaves and fruits. CVC was related to nutritional changes in citrus plants, one of the several hypotheses proposed for the cause of this anomaly, which also included virotic infection or toxicity by herbicides (Malavolta et al., 1992). It has been proved that the pathogen that causes CVC is the bacterium $X$. fastidiosa (Rossetti et al., 1990; Chang et al., 1993; Hartung et al., 1994). However, there are considerable disagreements on the mechanism of pathogenesis. Basic and important questions of how CVC establishes in the host is still unanswered. Dysfunction of the water-conducing system (Hopkins, 1989), caused by vascular occlusions (bacterial aggregates, host gum, and tyloses), phytotoxin (Mircetich et al., 1976; Lee et al., 1982) and growth regulator imbalances (French and Kitajima, 1978) were proposed mechanisms of pathogenesis. Another hypothesis raised by this study is based on an overall nutritional imbalance in the host, especially because micronutrient deficiency, which may enhance susceptibility to diseases caused by soil borne/foliar pathogens.

The mineral content of plant parts, in particular leaves, is used to identify nutrient deficiencies, excesses or imbalances within a crop (Storey and Treeby, 2000). Malavolta et al. (1993) have reported the macro- and micronutrient contents of citrus leaves, with particular association to $\mathrm{K}$ deficiency.

The functions of each micronutrient help us to understand their importance in crop production. Boron is related to cell wall formation, sugar transport in plants, flower retention and pollen formation and germination; copper is necessary for carbohydrate and nitrogen metabolism; iron is involved in the production of chlorophyll and is a component of many enzymes associated with energy transfer, nitrogen reduction and fixation, and lignin formation; manganese is necessary in photosynthesis, nitrogen metabolism and to form other compounds required for plant metabolism; zinc is an essential component of various enzymes required for energy transformation, protein synthesis, and growth regulation; molybdenum is involved in enzyme systems related to nitrogen fixation by bacteria growing symbiotically; chloride is related to salt effects and electrical charge balance in physiological functions in plants.

Pathogens can acquire all of the nutrients needed for its survival from the host, except for iron (Ratledge and Dover, 2000). Because iron is an essential growth factor to all bacteria, they have a number of mechanisms for iron uptake. The best-studied system is concerned with iron sequestration and transport by specific chelators, termed siderophores, which are secreted by bacteria and fungi when this metal is present at very low concentrations. Comparing the values of association constant $(\mathrm{K})$ with iron for specific iron-binding organic acids, $\mathrm{K}$ of oxalic acid $\left(\mathrm{K}=10^{7.6}\right)$, citric acid $\left(\mathrm{K}=10^{17.3}\right)$ and $\mathrm{K}$ of the enterobactin siderophore $\left(\mathrm{K}=\geq 10^{45}\right)$ it is concluded that the latter have stronger affinity for this metal (Nguyen et al., 1998; Kalinowski et al., 2000). Thus, the iron-binding organic acids are less effective in the process of iron sequestration when compared to siderophores (Kalinowski et al., 2000).

In a previous work, we demonstrated that $X$. fastidios $31 b 9 a 5 c$ from citrus is able to produce iron-chelators (Silva-Stenico et al., 2005; Pacheco et al., 2006). In the xylem, there is a strong correlation between Fe and citric acid in exudate from numerous plants (Tiffin, 1970). The studies of White et al. (1981) also confirms that Fecitrate is the chemical form of $\mathrm{Fe}$ in normal xylem sap, therefore iron is not available for endophytic bacteria, which will suffer from iron deficiency for cell growth. Under such conditions, the bacterial production of siderophores is induced.

Several studies have been conducted in order to try to understand nutritional disorders in citrus plants (Vitti et al., 1989; Ricci et al., 2001). However, those studies are not performed in specific foliar areas, but in several parts of plants, such as fruits, roots or branches. The aim of this work was to study the mineral composition in specific foliar areas in different stages of infection in citrus.

\section{Material and Methods}

\subsection{Samples}

Symptomatic and non-symptomatic citrus leaves were collected from four different orchards located at Santa Rita do Passa Quatro (SR), Neves Paulista (NP), Gavião Peixoto (GP), and Paraíso (PR), all counties in the state of São Paulo, Brazil. The plant leaves were pulverised one month before harvesting, including nonsymptomatic trees.

The experiment was conducted on samples taken from sweet orange (Citrus sinensis [L.] Osbeck cv. Pera) trees. The procedure to collect samples was the same used by Rodrigues et al. (2003). The leaves were randomly collected from plants with and without symptom from 4 orchards. Leaves collected were the third and fourth near the fruit, which was generated in the spring, with approximately 6 months of age, in branches with fruits from 2 to $4 \mathrm{~cm}$ of diameter, in the medium height of the tree, trying to include all of the quadrants of the plant. Leaves were kept in labelled humid dark plastic bags and transported on ice to the laboratory ( 2 to 4 hours until delivery time). Samples were kept in a cold room $\left(10{ }^{\circ} \mathrm{C}\right)$ for 1 day before the processing. All the foliar areas were washed in distilled water, cut into pieces and then this material was dried at $65^{\circ} \mathrm{C}$ to constant weight. The samples were ground to guarantee homogenization. 
Specific areas were analysed in each leaf: non-symptomatic tree (A), non-symptomatic leaf (B), necrosed area (C), non-symptomatic area (D) and chlorotic area (E). The analyses were performed in triplicate.

Figure 1 shows the specific location of foliar areas taken for nutrient analysis. Figure 1a shows a citrus leave presenting CVC symptoms, whereas Figure 1b shows leaf disks, respectively from a non-symptomatic foliar area (1), chlorotic foliar area (2) and necrotic foliar area (3).

\subsection{Nutrient analysis}

Dried foliar areas $(0.5 \mathrm{~g})$ were wet digested in $5 \mathrm{~mL}$ of $\mathrm{HNO}_{3}$. The acid was added to the tubes and allowed to stand overnight at room temperature before the samples were heated on an aluminum block digester (Windrift Instruments, Perth, Australia). Tubes were cooled, made up to $20 \mathrm{~mL}$ with deionised water and the mixed solutions were allowed to settle overnight. Samples and standard solutions were matrix-matched with respect to the acid and its concentration. The micronutrients $\mathrm{Fe}$, $\mathrm{Mn}, \mathrm{Cu}$ and $\mathrm{Zn}\left(\mathrm{mg} \cdot \mathrm{kg}^{-1}\right)$ and macronutrients $\mathrm{K}, \mathrm{Ca}$ and $\mathrm{Mg}\left(\mathrm{g}_{\mathrm{kg}} \mathrm{kg}^{-1}\right)$ were determined by atomic absorption spectrophotometry; B was measured by dry ashing (mg.kg-1) (Chapman and Pratt, 1961) and subsequent measurement by colorimetry using azomethine-H (Bingham, 1982), $\mathrm{P}$ and $\mathrm{S}$ were determined colorimetrically $\left(\mathrm{g}_{\mathrm{gg}} \mathrm{kg}^{-1}\right)$ (Malavolta et al., 1989).

\subsection{Chemometric analysis}

In the previous section a total of 273 samples were analysed. One hundred and fifty five samples were collected in the first year and nine elements were determined (Fe, Mn, $\mathrm{Cu}, \mathrm{Zn}, \mathrm{K}, \mathrm{S}, \mathrm{P}, \mathrm{Ca}$ and $\mathrm{Mg}$ ). In the second year 118 samples were collected and, the nine elements described before, plus B were determined. In order to
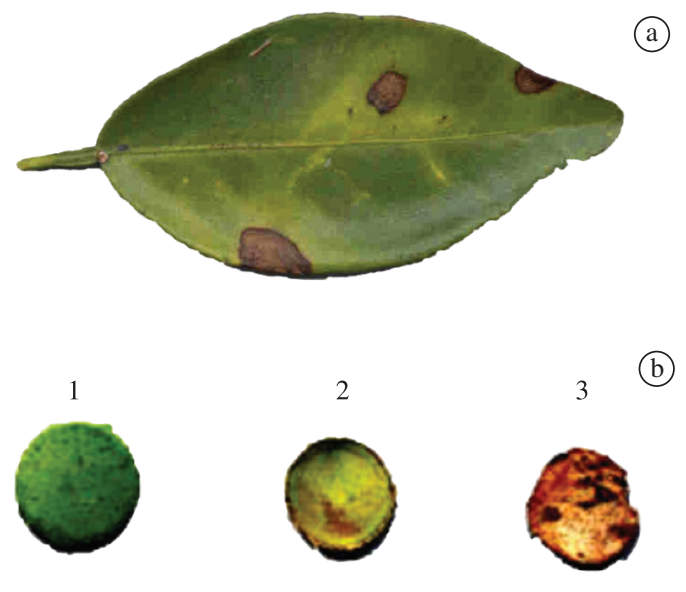

Figure 1. CVC symptoms in citrus leaves (a). Leaf disk area of a known diseased citrus plant used for nutrient measurement (b). Non-symptomatic foliar area (1); chlorotic foliar area (2); necrotic foliar area (3). maximise the information extraction from these data a Principal Component Analysis (PCA) (Wold et al., 1987; Brereton, 2000) was performed. This is a chemometric tool that allows a projection of the original data set in a smaller space named principal components (PC) providing data reduction and detection of clusters. In this case, the original data was divided in two matrices. The first one was composed by 155 samples (rows) and 9 variables - Fe, Mn, Cu, K, S, P, Ca and Mg (columns), the second was composed by 118 samples and 10 variables. The data was autoscaled and the PCA was calculated using Unscrambler version 7.2 (www.camo.com - Camo, Norway).

\subsection{Statistical analyses}

To evaluate the differences in concentration of nutrients among leaf populations (healthy leaf of non-symptomatic tree, healthy leaf of symptomatic tree, necrotic foliar area of symptomatic tree, non-symptomatic foliar area of symptomatic tree and chlorotic foliar area of symptomatic tree) a nonparametric Kruskall-Wallis test with an error probability of $5 \%$ was used. The post-hoc comparisons were performed with the Mann-Whitney nonparametric test, also with an error probability of $5 \%$. These analyses were performed using the software Statistica (version 5.5)

\subsection{Strain detection and identification}

To test whether $X$. fastidiosa could be detected from any part of the symptomatic and non-symptomatic leave tissue, disks ( $7 \mathrm{~mm}$ in diameter) of all leave parts were collected, DNA was extracted and amplified by the polymerase chain reaction (PCR) for strain detection and identification. Plant DNA extraction was developed according to Edwards et al. (1991).

PCR reactions using the designed primers (CVC-1 and 272-2) (Pooler and Hartung, 1995) specific for $X$. fastidiosa group were performed according to the following conditions: $25 \mathrm{ng}$ of genomic DNA, $2.0 \mathrm{mM}$ $\mathrm{MgCl}_{2}, 200 \mathrm{mM}$ dNTP, $50 \mathrm{ng}$ of each primer, $1.5 \mathrm{U}$ Taq DNA polymerase, buffer as recommended (Gibco-BRL) and water to $50 \mu \mathrm{L}$. The PCR cycling condition was programmed for $10 \mathrm{~min}$ at $94{ }^{\circ} \mathrm{C}$, followed by 30 cycles of $94{ }^{\circ} \mathrm{C}$ for $1 \mathrm{~min}, 60{ }^{\circ} \mathrm{C}$ for 1 minute and $72{ }^{\circ} \mathrm{C}$ for 1 minute. After the final cycle, an additional extension step was performed at $72{ }^{\circ} \mathrm{C}$ for 10 minutes.

\section{Results and Discussion}

Using specific primers to detect $X$. fastidiosa in leaves, it was verified that the bacteria is distributed in all parts of the leaf, including necrotic areas and nonsymptomatic leaf (Figure 2). Despite that $X$. fastidiosa is normally found in plant vessels (Leite et al., 2002), it was observed by using specific primers that $\mathrm{X}$. fastidiosa could be found in leave tissues.

The results of analysis of macro and micronutrients concentration were also evaluated using PCA. The first set of samples (matrix $155 \times 9$ ) was decomposed in two 
new matrices named scores and loadings. The scores have information about samples and the loadings have information about variables. Both sets of information must be visualised together. Figure 3 shows the scores

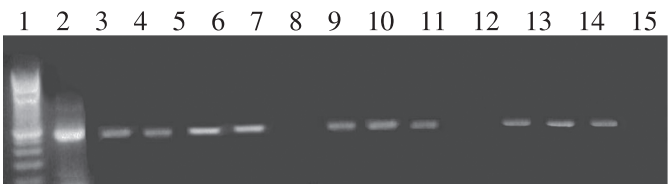

Figure 2. Ethidium bromide-stained agarose gel of PCR products after amplification with primers designed as CVC-1 and 272-2: Neves Paulista (NP), Gavião Peixoto (GP) and Santa Rita do Passa Quatro (SR). Numbers above lanes refer to: 1) Molecular marker $1 \mathrm{~kb}$ ladder; 2) X. fastidiosa (control); 3) Nonsymptomatic leaf of GP; 4) Nonsymptomatic foliar area of GP; 5) Chlorotic foliar area of GP; 6) Necrotic foliar area of GP; 7) Nonsymptomatic leaf of NP; 8) Nonsymptomatic foliar area of NP; 9) Chlorotic foliar area of NP; 10) Necrotic foliar area of NP; 11) Nonsymptomatic leaf of SR; 12) Nonsymptomatic foliar area of SR; 13) Chlorotic foliar area of SR; 14) Necrotic foliar area of SR; 15) negative control.
(3A) and the loadings (3B). In the scores plot it is possible to see that the samples A and B (non-symptomatic tree and leaf, respectively - open squares and triangles) were clustered and positioned at the superior part of the plot. Samples E (chlorotic area - black circles) were positioned at the inferior part of the scores. Samples C and D (necrosed and non-symptomatic area, respectively - black triangles and open circles) were positioned between both groups commented before. These clusters presented in the scores plot were linked with the following elements: $\mathrm{K}$ (positioned at the superior part of the loadings plot) connected to samples A and B; Zn, Mn, $\mathrm{Cu}$ and $\mathrm{Fe}$ related to samples $\mathrm{E}$. This behaviour indicates that samples A and B have more $\mathrm{K}$ than the other samples. Similarly samples E have more $\mathrm{Zn}, \mathrm{Mn}, \mathrm{Cu}$ and $\mathrm{Fe}$ than the others. The samples $\mathrm{C}$ and $\mathrm{D}$ have intermediate elements concentration. Finally it is concluded that in the chlorotic samples (E) the leaves incorporated these elements. In addition, the low or high content of $\mathrm{Zn}$ in leaves can be an indication of a chlorotic state.

The second set of samples $(118 \times 10)$ analysed by PCA confirmed comments stated on the previous paragraph. Figure 4 shows the scores (A) and loadings (B) plot. The chlorotic samples (E) were mainly related to
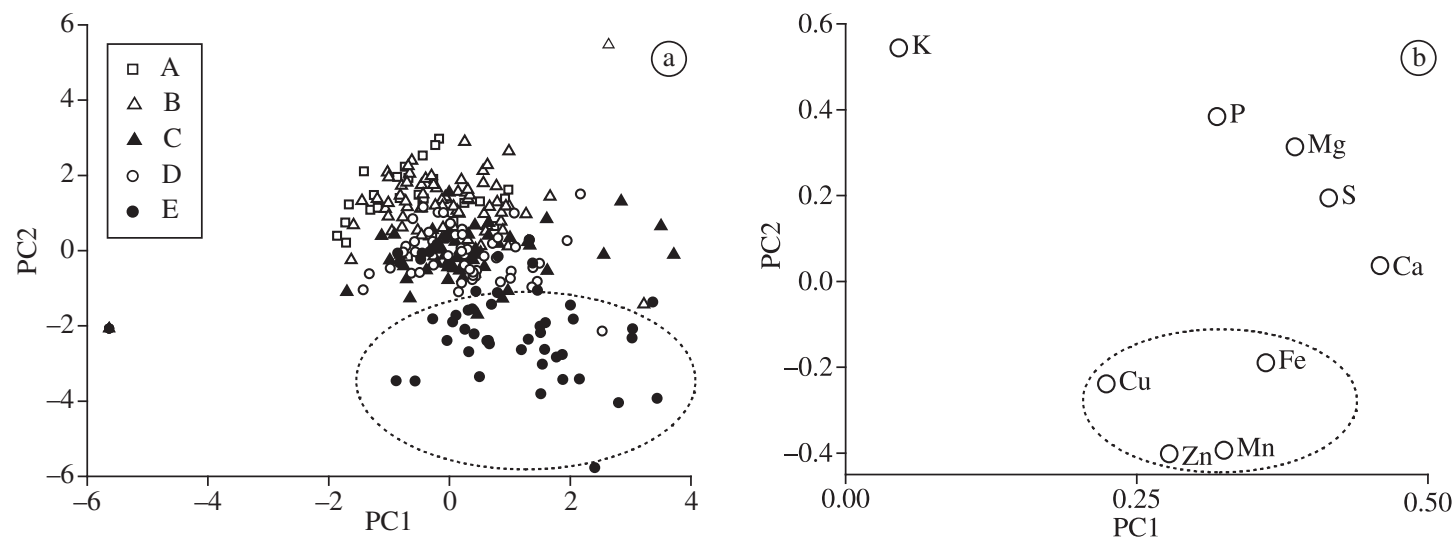

Figure 3. a) Scores and b) loadings plots for the first set of samples $(155 \times 9)$.

Table 1. Differences in nutrient concentrations observed in leaves of 4 orchards (average).

\section{Minerals}

\begin{tabular}{|c|c|c|c|c|c|c|c|c|c|c|}
\hline Samples & 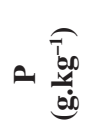 & 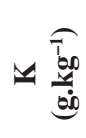 & ن & 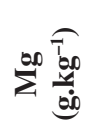 & 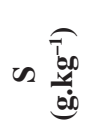 & 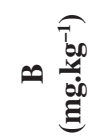 & 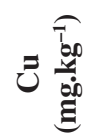 & 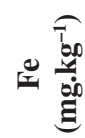 & 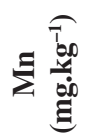 & 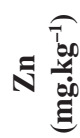 \\
\hline A & $1.4 \mathrm{a}$ & $17 \mathrm{a}$ & $30 \mathrm{a}$ & $3.9 a$ & $2.5 \mathrm{a}$ & $27 \mathrm{a}$ & $113 a$ & $42 a$ & $32 a$ & $34 a$ \\
\hline B & $1.4 \mathrm{a}$ & $15 b$ & $33 \mathrm{ad}$ & $3.9 a$ & $3.2 b$ & $28 \mathrm{ab}$ & $132 \mathrm{a}$ & $56 a$ & $31 \mathrm{a}$ & $45 b$ \\
\hline $\mathrm{C}$ & $0.9 b$ & $7 \mathrm{c}$ & $42 b$ & $4.2 \mathrm{a}$ & $3.3 b$ & $47 \mathrm{abc}$ & $208 b$ & $75 b$ & $44 \mathrm{~b}$ & $45 b$ \\
\hline D & $0.9 b$ & $7 \mathrm{c}$ & $43 b$ & $4.2 \mathrm{a}$ & $3.1 \mathrm{~b}$ & $42 \mathrm{ac}$ & $210 \mathrm{~b}$ & $67 b$ & $49 b$ & $70 \mathrm{c}$ \\
\hline $\mathrm{E}$ & $1.2 \mathrm{c}$ & $3 d$ & $35 \mathrm{~d}$ & $3.2 \mathrm{~b}$ & $3.1 \mathrm{~b}$ & $134 d$ & $242 b$ & $198 \mathrm{c}$ & $120 \mathrm{c}$ & $106 d$ \\
\hline
\end{tabular}

A - Healthy leaf of non-symptomatic tree; B - Healthy leaf of symptomatic tree; C - Necrotic foliar area of symptomatic tree; D - Non-symptomatic foliar area of symptomatic tree; and E - Chlorotic foliar area of symptomatic tree. 

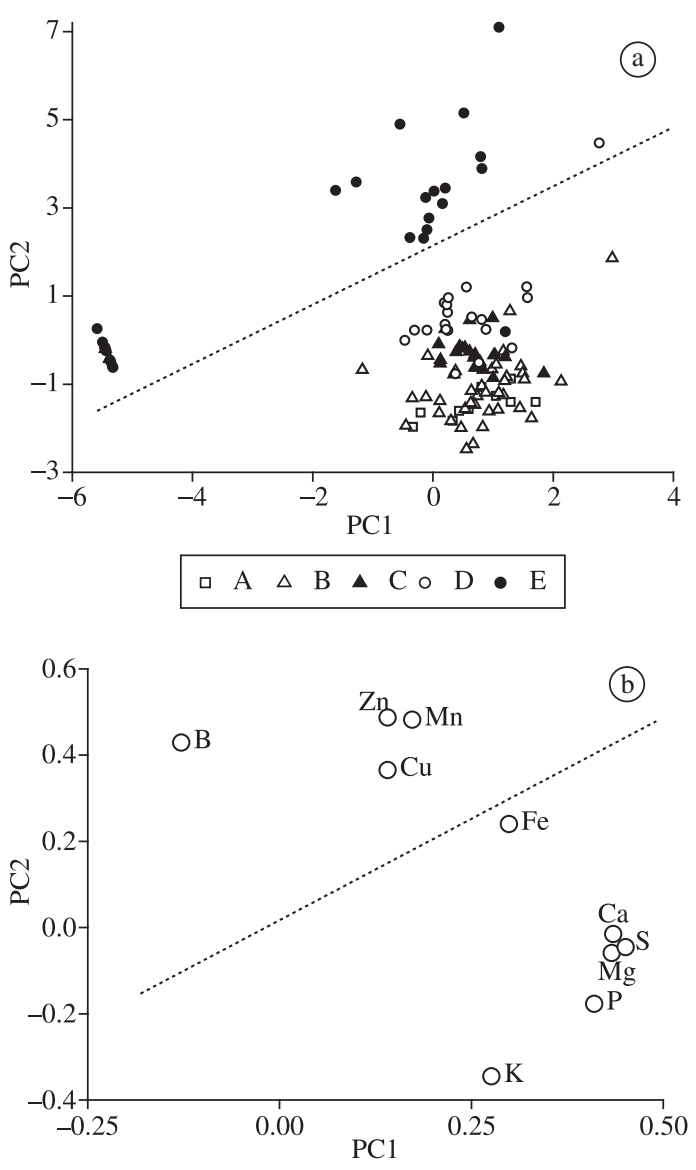

Figure 4. a) Scores and b) loadings plots for the second set of samples $(118 \times 10)$.

$\mathrm{Zn}, \mathrm{Mn}, \mathrm{Cu}, \mathrm{Fe}$ and, now B. In the scores plot (Figure 4a) a clear division between samples $\mathrm{E}$ and the others is seen. Samples A, B, C, and D have high K, P, Mg, S and $\mathrm{Ca}$ content. The information visualised in Figures 3 and 4 was confirmed using statistical tests (Kruskal-Wallis $\mathrm{p}<0.05$ and Mann-Whitney) (Table 1) and it was also observed that the chlorotic samples (E) presented distinct elements concentration when compared with the other samples.

Vitti and co-authors (1989) studied the nutritional deficiency in citrus and found that they presented nutritional disorders such as low potassium and zinc concentrations, which was not related to the nutrients availability in the soil. Another nutritional study in several parts of the plant presenting CVC symptoms showed that the lower concentrations of $\mathrm{N}, \mathrm{P}$ and $\mathrm{Mg}$ could be found in those trees in comparison with the healthy ones (Ricci et al., 2001).

In conclusion, this is the first time that foliar disk analysis revealed nutritional disorders depending on the foliar area studied and it is always accompanied by significant alterations in the levels of some nutrients. Chemometric analysis showed that the deficiency of $\mathrm{P}$ and $\mathrm{K}$ in symptomatic trees for all orchards and high concentrations of $\mathrm{Fe}, \mathrm{Mn}$ and $\mathrm{Zn}$ were present in chlorotic areas, although other studies revealed deficiency of zinc in leaves (Beretta et al., 1997). According to the analysis, the deficiency of $\mathrm{P}$ and $\mathrm{K}$ in symptomatic trees for all orchards and high concentrations of $\mathrm{Fe}, \mathrm{Mn}$ and $\mathrm{Zn}$ present in chlorotic areas of symptomatic trees, may or may not be influenced by the causal agent.

Acknowledgements - The authors thank Wagner Piccinini and Fábio R. Duarte for plant sampling. M.E.S.-S. (00/08045-3) and F.T.H.P. (99/07748-1) are grateful for the financial support from the Fundação de Amparo à Pesquisa do Estado de São Paulo (FAPESP). This project was supported by FAPESP (Grant 98/16265-1). The authors are also grateful to Conselho Nacional de Desenvolvimento Científico e Tecnológico (CNPq).

\section{References}

BERETTA, MJG., BARTHE, GA., CECCARDI, TL., LEE, RF. and DERRICK, KS., 1997. A survey for strains of Xylella fastidiosa in citrus affected by citrus variegated chlorosis and citrus blight in Brazil. Plant Disease, vol. 81, no. 10, p. 1196-1198.

BINGHAM, F., 1982. Methods of soil analysis: parte 2 . Madison: American Society of Agronomy. p. 431-447.

BRERETON, RG., 2000. Introduction to multivariate calibration in analytical chemistry. Analyst, vol. 125, no. 11, p. 2125-2154.

CHANG, CJ., GARNIER, M., ZREIK, L., ROSSETTI, V. and BOVE, JM., 1993. Culture and serological detection of the xylem-limited bacterium causing citrus variegated chlorosis and its identification as a strain of Xylella fastidiosa. Current Microbiology, vol. 27, no. 3, p. 137-142.

CHAPMAN, H. and PRATT, PF., 1961. Methods of analysis for soils, plants and water. Belmont: Wadsworth Publishing. p. 309.

EDWARDS, K., JOHNSTONE, C. and THOMPSON, C., 1991. A simple and rapid method for the preparation of plant genomic DNA for PCR analysis. Nucleic Acids Research, vol. 19, no. 6, p. $1349-1349$.

FRENCH, WJ. and KITAJIMA, EW., 1978. Occurrence of plum leaf scald in Brazil and Paraguay. Plant Disease, vol. 62, no. 12 , p. 1035-1038.

HARTUNG, JS., BERETTA, J., BRLANSKY, RH., SPISSO, J. and LEE, RF., 1994. Citrus variegated chlorosis-bacterium - axenic culture, pathogenicity, and serological relationships with other strains of Xylella fastidiosa. Phytopathology, vol. 84, no. 6, p. 591-597.

HOPKINS, DL., 1989. Xylella fastidiosa - xylem-limited bacterial pathogen of plants. Annual Review of Phytopathology, vol. 27, p. 271-290.

KALINOWSKI, BE., LIERMANN, LJ., GIVENS, S. and BRANTLEY, SL., 2000. Rates of bacteria-promoted solubilization of Fe from minerals: a review of problems and approaches. Chemical Geology, vol. 169, no. 3-4, p. 357-370.

LEE, RF., RAJU, BC., NYLAND, G. and GOHEEN, AC., 1982. Phytotoxin(s) produced in culture by the pierces disease bacterium. Phytopathology, vol. 72, no. 7, p. 886-888. 
LEITE, B., ISHIDA, ML., ALVES, E., CARRER, H., PASCHOLATI, SF. and KITAJIMA, EW., 2002. Genomics and $\mathrm{X}$-ray microanalysis indicate that $\mathrm{Ca}^{2+}$ and thiols mediate the aggregation and adhesion of Xylella fastidiosa. Brazilian Journal of Medical and Biological Research, vol. 35, no. 6, p. 645-650.

MALAVOLTA, E., PRATES, HS. and PINTO, WBS., 1992. Levantamento e observações sobre o amarelinho ou clorose variegada dos citros. Laranja, vol. 13, no. 2, p. 503-514.

MALAVOLTA, E., PRATES, HS., VITTI, GC. and PINTO, WBS., 1993. Novas observações sobre o "amarelinho" ou clorose variegada dos citros. Laranja, vol. 14, no. 1, p. 177-200.

MALAVOLTA, E., VITTI, GC. and OLIVEIRA, SA., 1989. Avaliação do estado nutricional das plantas: princípios e aplicações. Piracicaba: Associação Brasileira para Pesquisa da Potassa e do Fosfato. p. 201.

MIRCETICH, SM., LOWE, SK., MOLLER, WJ. and NYLAND, G., 1976. Etiology of almond leaf scorch disease and transmission of causal agent. Phytopathology, vol. 66, no. 1 , p. 17-24.

NGUYEN, M., NICOLAS, L., GAUDEMER, A. and BRIK, ME., 1998. Synthesis and ESR study of new dihydroxamic acid siderophores $\mathrm{S}$ as scavengers of hydroxyl radicals. Bioorganic and Medicinal Chemistry Letters, vol. 8, no. 3, p. 227-232.

PACHECO, FTH., SILVA-STENICO, ME., ETCHEGARAY, A., GOMES, JE., CARRILHO, E. and TSAI, SM., 2006. Specific amplification of iron receptor genes in Xylella fastidiosa strains from different hosts. Genetics and Molecular Biology, vol. 29, no. 1, p. $137-141$

POOLER, MR. and HARTUNG, JS., 1995. Specific PCR detection and identification of Xylella fastidiosa strains causing citrus variegated chlorosis. Current Microbiology, vol. 31, no. 6 , p. $377-381$.

RATLEDGE, C. and DOVER, LG., 2000. Iron metabolism in pathogenic bacteria. Annual Review of Microbiology, vol. 54, p. 881-941.
RICCI, A., MOURÃO-FILHO, FAA., ARAÚJO, PSR., BERETTA, MJG. and DERRICK, K., 2001. Teores de nutrientes em laranjeiras "Pêra" em função da clorose variegada dos citros. Laranja, vol. 22, no. 2, p. 517-531.

RODRIGUES, JLM., SILVA-STENICO, ME., GOMES, JE., LOPES, J. and TSAI, SM., 2003. Detection and diversity assessment of Xylella fastidiosa in field-collected plant and insect samples by using 16S rRNA and gyrB sequences. Applied and Environmental Microbiology, vol. 69, no. 7, p. 4249-4255.

ROSSETTI, V., GARNIER, M., BOVE, JM., BERETTA, MJG., TEIXEIRA, ARR., QUAGGIO, JÁ. and DENEGRI, JD., 1990. Occurrence of xylem-restricted bacteria in sweet orange trees affected by chlorotic variegation, a new citrus disease in Brazil. Les Comptes rendus de l'Académie des sciences, vol. 310, p. 345-349.

SILVA-STENICO, ME., PACHECO, FTH., RODRIGUES, JLM., CARRILHO, E. and TSAI, SM., 2005. Growth and siderophore production of Xylella fastidiosa under ironlimited conditions. Microbiological Research, vol. 160, no. 4, p. 429-436.

STOREY, R. and TREEBY, MT., 2000. Seasonal changes in nutrient concentrations of navel orange fruit. Scientia Horticulturae, vol. 84, no. 1-2, p. 67-82.

TIFFIN, LO., 1970. Translocation of iron citrate and phosphorus in xylem exudates of soybean. Plant Physiology, vol. 45, no. 3, p. $280-283$.

VITTI, GC., MARCHI, RJ., BORELLA, ML. and VAZ FILHO, D., 1989. Estudo de prováveis desequilíbrios nutricionais em pomares cítricos no município de Colina-SP. In: Boletins da FCAV/Unesp. Jaboticabal: UNESP. 12 p.

WHITE, MC., BAKER, FD., CHANEY, RL. and DECKER, AM., 1981. Metal complexation in xylem fluid. II. Theoretical equilibrium model and computational computer program. Plant Physiology, vol. 67, no. 2, p. 301-310.

WOLD, S., ESBENSEN, K. and GELADI, P., 1987. Principal component analysis. Chemometrics and Intelligent Laboratory Systems, vol. 2, no. 1-3, p. 37-52. 